\title{
Evaluation of inflammatory response in patients undergoing surgical treatment for early and delayed femoral fractures
}

Mehdi Moghtadaei ${ }^{1}$, Babak Otoukesh ${ }^{1}$, Hamidreza Pazoki-Toroudi ${ }^{2}$, Bahram Boddouhi ${ }^{1}$, Ali Yeganeh ${ }^{1}$

\begin{abstract}
${ }^{1}$ Bone and Joint Reconstruction Research Center, Shafa Orthopedic Hospital, Iran University of Medical Science, Tehran, Iran

2Physiology Research Center, Department of Physiology, Faculty of Medicine, Iran University of Medical Sciences, Tehran, Iran
\end{abstract}

Submitted: 17 July 2016

Accepted: 21 August 2016

Arch Med Sci 2019; 15, 1: 141-145

DOI: https://doi.org/10.5114/aoms.2016.63013

Copyright $\odot 2016$ Termedia \& Banach

\section{Abstract}

Introduction: It has been shown that long bone fractures are correlated with the inflammatory response. In the initial injury, surgical reduction and fixation of fractures induce the immunoinflammatory response. This study aimed to evaluate serum variation of inflammatory markers in patients undergoing surgical treatment for early and delayed femoral fractures.

Material and methods: This study aimed to evaluate serum variation of inflammatory markers in patients undergoing surgical treatment for early and delayed femoral fractures. The patients were randomly divided into two groups using the method of block randomization including early surgery (within $24 \mathrm{~h}$ ) and delayed surgery (after $48 \mathrm{~h}$ ). Serum levels of inflammatory markers in both groups including interleukin (IL)-1, 5, 6, tumor necrosis factor $\alpha$ (TNF- $\alpha)$ and interferon $\gamma($ IFN- $\gamma$ ) were determined using specific kits. From each patient $10 \mathrm{ml}$ blood was collected for cytokine assay in their serum.

Results: Our findings suggest that serum levels of IL- 8 were markedly decreased from $12 \mathrm{~h}$ until $48 \mathrm{~h}$ postoperatively $(p<0.05)$. Moreover, the results indicated that serum levels of TNF- $\alpha$ were significantly increased in the early hours, but after $48 \mathrm{~h}$ a decreasing trend was detected $(p<0.05)$. Furthermore, serum levels of IL-10, IFN- $\gamma$, and IL- 6 were significantly increased from $12 \mathrm{~h}$ until $48 \mathrm{~h}$ postoperatively $(p<0.05)$.

Conclusions: The inflammatory status of the patient may be a useful adjunct in clinical decisions. With an improved understanding of the molecular basis of the inflammatory response, and by identifying relevant clinical markers of inflammation, surgeons can better manage the timing of surgical stabilization.

Key words: inflammation, tumor necrosis factor, interleukin, patient, femoral.

\section{Introduction}

The inflammatory response has been recognized as a physiologic reaction to injury. Surgery was shown to be the cause of a systemic response, the extent of which is moderated by different parameters such as the health and nutritional status of the patient, the severity of recent trauma and the presence of any preexisting physiologic derangement, and

\author{
Corresponding author: \\ Assoc. Prof. Ali Yeganeh \\ Rasoul Akram Hospital \\ Iran University \\ of Medical Sciences \\ Tehran, Iran \\ Phone: +98 9122187996 \\ E-mail: yeganeh471@ \\ yahoo.com
}


the magnitude, duration, and technique of surgery [1-4]. It has been shown that hip fracture and surgery in aged rats induced a systemic inflammatory response and lung injury correlated with increased susceptibility to infection during the acute phase after injury and surgery. It has been shown that long bone fractures are correlated with the development of the systemic inflammatory response syndrome and are strongly associated with multi-organ failure, sepsis, hospital length of stay, and mortality [5-7]. Different components of the immune system have been demonstrated to be involved in this process, such as inflammatory cytokines, leukocyte adhesion molecules, growth factors, nitric oxide, platelet-activating factors, and the activation of local and systemic polymorphonuclear neutrophils (PMNs), lymphocytes, and macrophages. This complex response arises from the interplay between various mediators produced at the site of injury, including cytokines [8]. These mediators can regulate gene transcription, and modify intracellular signaling pathways [9]. In the initial injury, surgical reduction and fixation of fractures induce the immunoinflammatory response [10]. Therefore, modulation of cytokine release has been considered a tempting strategy [11]. This study aimed to evaluate serum variation of inflammatory markers in patients undergoing surgical treatment for early and delayed femoral fractures.

\section{Material and methods}

\section{Patients and serum parameters}

This study is a randomized clinical trial and all samples were conducted among patients with femoral fractures, between 2014 and 2015 in Rasol Hospital of Tehran. This study was approved by the Ethical Committee for Clinical Research of the Hospital, and informed consent was obtained from all the patients. It is worth noting that the criteria included ages of 20 to 50 years, and patients with femoral shaft fractures without injury in other parts of the body were recruited for our study. The patients were randomly divided into two groups using the method of block randomization including early surgery (within $24 \mathrm{~h}$ ) and delayed surgery (after $48 \mathrm{~h}$ ). Serum levels of inflammatory markers in both groups including interleukin (IL)-1, 5, 6, tumor necrosis factor (TNF)- $\alpha$ and interferon (IFN)- $\gamma$ were determined by specific kits. From each patient $10 \mathrm{ml}$ of blood was collected for cytokine assay in their serum.

Patients with the following criteria were excluded from the study: patients who had chronic inflammatory disease or a history of trauma in the last month, patients who had suffered multiple organ damage in their recent trauma, and patients with complex fractures.

\section{ELISA analysis}

Serum was also separated from blood using centrifugation $\left(2000 \times \mathrm{g}\right.$ for $15 \mathrm{~min}$ at $4^{\circ} \mathrm{C}$ ). All samples were frozen at $-20^{\circ} \mathrm{C}$ in sterile tubes until used for cytokine measurements by the ELISA method using commercial kits (BIORBYT).

\section{Statistical analysis}

All variables were analyzed using the software SPSS version 16.0 (SPSS Inc, IL, USA). To compare levels of inflammatory markers including IL-1, IL-5, IL-6, TNF- $\alpha$ and IFN- $\gamma$ the independent $t$-test was used. Differences were considered statistically significant when $p$ was less than 0.05 .

\section{Results}

Our findings suggest that serum levels of IL-8 were markedly decreased from $12 \mathrm{~h}$ until $48 \mathrm{~h}$ postoperatively $(p<0.05)$. Moreover, the results indicated that serum levels of TNF- $\alpha$ were significantly increased in the early hours, but after $48 \mathrm{~h}$ a decreasing trend was detected $(p<0.05)$. Furthermore, serum levels of IL-10, IFN- $\gamma$, and IL-6 were significantly increased from $12 \mathrm{~h}$ until $48 \mathrm{~h}$ postoperatively $(p<0.05)$ (Table I).

\section{Discussion}

The complex inflammatory response arises from the interplay between various mediators produced at the site of injury, including cytokines [8]. These mediators can regulate gene transcription, and modify intracellular signaling pathways [9]. In the initial injury, surgical reduction and fixation of fractures induce the immunoinflammatory response. Therefore, modulation of cytokine release has been considered a tempting strategy [10]. Zhang et al. reported that hip fracture and surgery in aged rats induced a systemic inflammatory response and lung injury correlated with increased susceptibility to infection during the acute phase after injury and surgery [11].

In the present study, our findings suggest that serum levels of IL-8 were markedly decreased from $12 \mathrm{~h}$ until $48 \mathrm{~h}$ postoperatively. Moreover, the results indicated that serum levels of TNF- $\alpha$ were significantly increased in the early hours, but after $48 \mathrm{~h}$ a decreasing trend was detected. Furthermore, serum levels of IL-10, IFN- $\gamma$, and IL-6 were significantly increased from $12 \mathrm{~h}$ until $48 \mathrm{~h}$ postoperatively.

Neumaier et al. [12] reported that the C-reactive protein (CRP) values were significantly lower in early surgery within $24 \mathrm{~h}$ after trauma than in delayed surgery. Moreover, they found that a lower postoperative inflammatory reaction after early surgery of hip fractures provides a better out- 
Table I. Comparison of serum levels of inflammatory markers in patients with different times

\begin{tabular}{|c|c|c|c|c|c|c|c|}
\hline $\begin{array}{l}\text { Number } \\
\text { of patient }\end{array}$ & Gender & $\begin{array}{l}\text { Sampling } \\
\text { dates and } \\
\text { times }\end{array}$ & $\begin{array}{c}\text { IL-8 } \\
\text { concentration }\end{array}$ & $\begin{array}{c}\text { TNF- } \alpha \\
\text { concentration }\end{array}$ & $\begin{array}{c}\text { IL-6 } \\
\text { concentration }\end{array}$ & $\mathrm{IFN}-\gamma[\mathrm{ng} / \mu \mathrm{l}]$ & $\mathrm{IL}-10[\mathrm{ng} / \mu \mathrm{l}]$ \\
\hline 1 & M & 0 & & 0 & & & \\
\hline 2 & $M$ & $24 \mathrm{~h}$ & & & & & \\
\hline 3 & $M$ & $48 \mathrm{~h}$ & 0 & & & & 46.439 \\
\hline 4 & $M$ & 0 & 0 & & & & 32.874 \\
\hline 5 & $M$ & $24 \mathrm{~h}$ & & 0 & & & \\
\hline 6 & $M$ & $48 \mathrm{~h}$ & & 0 & & & \\
\hline 7 & $M$ & $48 \mathrm{~h}$ & 0 & 0 & 88.27 & 108.474 & 258.598 \\
\hline 8 & $M$ & $24 \mathrm{~h}$ & 0 & 28.871 & 374.836 & 0 & 164.614 \\
\hline 9 & $M$ & 0 & 0 & 1.679 & 56.695 & 141.466 & 572.878 \\
\hline 10 & $\mathrm{~F}$ & $48 \mathrm{~h}$ & 57.992 & 135.058 & 393.762 & 104.554 & 395.093 \\
\hline 11 & $\mathrm{~F}$ & $24 \mathrm{~h}$ & 0 & 0 & 29.466 & 2.842 & 130.332 \\
\hline 12 & $\mathrm{~F}$ & 0 & 35.064 & 176.806 & 314.69 & 78.371 & 576.652 \\
\hline 13 & $M$ & 0 & 0 & 0 & 76.802 & 11.52 & 118.66 \\
\hline 14 & $M$ & $48 \mathrm{~h}$ & 0 & 0 & 55.636 & 11.52 & 86.575 \\
\hline 15 & $M$ & $24 \mathrm{~h}$ & 0 & 0 & 67.127 & 1.066 & 167.327 \\
\hline 16 & $M$ & 0 & 0 & 37.275 & 79.316 & 6.946 & 580.454 \\
\hline 17 & $M$ & $24 \mathrm{~h}$ & 0 & 33.393 & 64.027 & 0 & 416.276 \\
\hline 18 & $M$ & $48 \mathrm{~h}$ & 0 & 0 & 60.903 & 16.441 & 13.428 \\
\hline 19 & M & $48 \mathrm{~h}$ & 0 & 7.839 & 48.118 & 0 & 492.988 \\
\hline 20 & $M$ & $24 \mathrm{~h}$ & & 22.465 & 131.388 & 61.03 & 159.263 \\
\hline 21 & $M$ & $48 \mathrm{~h}$ & 0 & 0 & 66.612 & 4.822 & 23.186 \\
\hline 22 & $M$ & $24 \mathrm{~h}$ & 0 & 318.514 & 128.109 & 19.013 & 1479.571 \\
\hline 23 & $M$ & 0 & 0 & 357.436 & 107.241 & 41.772 & 1476.714 \\
\hline 24 & $M$ & 0 & 0 & 0 & 28.277 & & 67.388 \\
\hline 25 & $M$ & $48 \mathrm{~h}$ & 0 & 0 & 20.93 & 54.418 & 32.107 \\
\hline 26 & $\mathrm{~F}$ & $24 \mathrm{~h}$ & 0 & 1.679 & 46.482 & 93.063 & 1346.595 \\
\hline 27 & $\mathrm{~F}$ & 0 & 0 & 2.549 & 21.558 & 96.848 & 943.885 \\
\hline 28 & $M$ & $24 \mathrm{~h}$ & 0 & 0 & 70.716 & 4.822 & 11.433 \\
\hline 29 & $M$ & $24 \mathrm{~h}$ & 0 & 0 & 58.805 & 6.946 & 9.475 \\
\hline 30 & $M$ & 0 & 0 & 0 & 612.362 & 11.52 & 24.638 \\
\hline 31 & $M$ & $48 \mathrm{~h}$ & 0 & 228.051 & 202.519 & 9.184 & 1441 \\
\hline 32 & $M$ & $48 \mathrm{~h}$ & 0 & 0 & 148.101 & 29.939 & 35.193 \\
\hline 33 & $M$ & $24 \mathrm{~h}$ & 0 & 0 & 214.574 & 89.322 & 94.726 \\
\hline 34 & $M$ & 0 & 0 & 0 & 180.941 & 74.811 & 74.866 \\
\hline 35 & $M$ & $24 \mathrm{~h}$ & 0 & 28.871 & 4.063 & 196.526 & 85.576 \\
\hline 36 & $M$ & $48 \mathrm{~h}$ & 0 & 91.92 & 185.003 & 4.822 & 315.489 \\
\hline 37 & $M$ & 0 & 0 & & & & \\
\hline 38 & $M$ & $24 \mathrm{~h}$ & 0 & 66.171 & 115.362 & 64.406 & 230.739 \\
\hline 39 & $M$ & 0 & & & & & \\
\hline 40 & $M$ & $24 \mathrm{~h}$ & 0 & 0 & 72.753 & 0 & 15.458 \\
\hline 41 & $M$ & $\mathrm{Oh}$ & 0 & 0 & 155 & 0 & 49.781 \\
\hline 42 & $M$ & $48 \mathrm{~h}$ & 0 & 0 & 350.672 & 4.822 & 61.946 \\
\hline 43 & $M$ & 0 & & 0 & & & \\
\hline 44 & $M$ & $24 \mathrm{~h}$ & 0 & 24.823 & 253.136 & 74.811 & 86.575 \\
\hline 45 & $M$ & $24 \mathrm{~h}$ & 0 & & 117.261 & 201.428 & 37.545 \\
\hline
\end{tabular}


Table I. Cont.

\begin{tabular}{|c|c|c|c|c|c|c|c|}
\hline $\begin{array}{l}\text { Number } \\
\text { of patient }\end{array}$ & Gender & $\begin{array}{l}\text { Sampling } \\
\text { dates and } \\
\text { times }\end{array}$ & $\begin{array}{c}\text { IL-8 } \\
\text { concentration }\end{array}$ & $\begin{array}{c}\text { TNF- } \alpha \\
\text { concentration }\end{array}$ & $\begin{array}{c}\text { IL-6 } \\
\text { concentration }\end{array}$ & $\mathrm{IFN}-\gamma[\mathrm{ng} / \mu \mathrm{ll}]$ & $\mathrm{IL}-10[\mathrm{ng} / \mu \mathrm{l}]$ \\
\hline 46 & $M$ & $48 \mathrm{~h}$ & & 0 & 77.306 & 74.811 & 197.418 \\
\hline 47 & $M$ & $24 \mathrm{~h}$ & 0 & 0.722 & 70.205 & 145.795 & 237.491 \\
\hline 48 & $M$ & 0 & 0 & 1.679 & 86.787 & 0 & 279.141 \\
\hline 49 & $M$ & 0 & 0 & 20.067 & 59.856 & 0 & 17.522 \\
\hline 50 & $\mathrm{~F}$ & $48 \mathrm{~h}$ & 0 & 0 & 127.64 & 0 & 24.638 \\
\hline 51 & $\mathrm{~F}$ & $24 \mathrm{~h}$ & 0 & 0 & 148.562 & 0 & 11.433 \\
\hline 52 & $\mathrm{~F}$ & 0 & 0 & 0 & 38.141 & 11.52 & 32.874 \\
\hline 53 & $M$ & $48 \mathrm{~h}$ & 0 & 0 & 123.879 & 120.506 & 80.645 \\
\hline 54 & M & $24 \mathrm{~h}$ & 0 & 0 & 66.097 & 137.182 & 74.866 \\
\hline 55 & $M$ & 0 & 0 & 2.549 & 46.482 & 0 & 37.545 \\
\hline 56 & $M$ & $48 \mathrm{~h}$ & 0 & 0 & 39.27 & 0 & 11.433 \\
\hline 57 & $\mathrm{~F}$ & $24 \mathrm{~h}$ & 0 & 0 & 108.68 & 0 & 12.759 \\
\hline 58 & $\mathrm{~F}$ & 0 & 0 & 0 & 31.234 & 0 & 17.522 \\
\hline 59 & $M$ & $24 \mathrm{~h}$ & 0 & 0 & 113.458 & 16.441 & 38.335 \\
\hline 60 & $\mathrm{~F}$ & $24 \mathrm{~h}$ & 0 & 20.067 & 177.323 & 54.418 & 253.198 \\
\hline 61 & $\mathrm{~F}$ & 0 & 0 & 11.905 & 29.466 & 51.183 & 55.772 \\
\hline 62 & M & 0 & 0 & 19.461 & 42.069 & 54.418 & 35.973 \\
\hline 63 & $M$ & $48 \mathrm{~h}$ & 0 & 0 & 50.285 & 29.939 & 21.748 \\
\hline 64 & $\mathrm{~F}$ & $48 \mathrm{~h}$ & 0 & 0 & 72.753 & 16.441 & 19.619 \\
\hline
\end{tabular}

come when treated with arthroplasty. Findings of Harwood et al. [13] support the continued use of damage control procedures in severely injured patients and complement data already available, suggesting that a damage control orthopedics (DCO) approach reduces the subsequent inflammatory response. Moreover, they concluded that the inflammatory status of the patient may be important in clinical decision making regarding the timing of conversion to an intramedullary device. In agreement with our study, they found that the pattern of serum IL-6, keratinocyte, IL-10, and IL-1 release was dynamic, but no significant elevation in TNF- $\alpha$ was detected. The early hepatic and pulmonary infiltration of polymorphonuclear cells occurred in the absence of significantly elevated serum cytokine levels, indicating that either early minor changes with an imbalance in inflammatory mediators or locally produced cytokines may initiate this process. Nakamura et al. in Japan reported that IL- 1 and IL- 6 and TNF- $\alpha$ were increased after femoral fractures and that they originated from synovial cells [14]. It has been reported that intramedullary nailing fixation resulted in an increase in the level of inflammatory cytokines in animal models. As a matter of fact, it has more adverse effects on the inflammatory response, system stress, and multiple organs [14].

A previous study found that the serum levels of IL-6 and IL-8 in the cerebrospinal fluid were increased, and it raises the possibility that IL-8, acting in the central nervous system (CNS), plays a role in the postinjury syndrome. The mechanism by which CNS IL-8 is produced in trauma is unclear, but a physiological role is supported by the known ability of the CNS to produce IL- 8 and the presence of receptors for its action in the CNS $[15,16]$.

In an animal model, it has been reported that immune cell performance can be increased, and this phenomenon results in an increase in cytokine secretion levels [17]. A previous study evaluated the change in IL- 6 levels perioperatively in patients treated for femoral shaft fracture. It was reported that damage control procedures provoked a significantly smaller increase in IL-6 levels when compared with those observed after primary intramedullary nail (IMN). Furthermore, similar studies on bone fracture were conducted previously by other authors [18-20]. In conclusion, the inflammatory status of the patient may be a useful adjunct in clinical decision making. With an improved understanding of the molecular basis of the inflammatory response, and by identifying relevant clinical markers of inflammation, surgeons can better manage the timing of surgical stabilization.

\section{Conflict of interest}

The authors declare no conflict of interest. 


\section{References}

1. Galle C, De Maertelaer V, Motte S. Early inflammatory response after elective abdominal aortic aneurysm repair: a comparison between endovascular procedure and conventional surgery. J Vasc Surg 2000; 32: 234-46.

2. Munoz M, Garcia-Vallejo JJ, Sempere JM, et al. Acute phase response in patients undergoing lumbar spinal surgery: modulation by perioperative treatment with naproxen and famotidine. Eur Spine J 2004; 13: 467-73.

3. Pape HC, Schmidt RE, Rice J, et al. Biochemical changes after trauma and skeletal surgery of the lower extremity: quantification of the operative burden. Crit Care Med 2000; 28: 3441-8.

4. Wakai A, Wang JH, Winter DC, et al. Tourniquet-induced systemic inflammatory response in extremity surgery. J Trauma 2001; 51: 922-6.

5. Faist E, Baue AE, Dittmer H, Heberer G. Multiple organ failure in polytrauma patients. J Trauma 1983; 23: 775-87.

6. Lane MK, Nahm NJ, Vallier HA. Morbidity and mortality of bilateral femur fractures. Orthopedics 2015; 38: e588-92.

7. Giannoudis PV, Cohen A, Hinsche A, et al. Simultaneous bilateral femoral fractures: systemic complications in 14 cases. Int Orthop 2000; 24: 264-7.

8. Rankin JA. Biological mediators of acute inflammation. AACN Clin Issues 2004; 15: 3-17.

9. Robinson CM. Current concepts of respiratory insufficiency syndromes after fracture. J Bone Joint Surg $\mathrm{Br}$ 2001; 83: 781-91.

10. Finnerty CC, Herndon DN, Przkora R, et al. Cytokine expression profile over time in severely burned pediatric patients. Shock 2006; 26: 13 Y19.

11. Zhang H, Sun T, Liu Z, Zhang J. Systemic inflammatory responses and lung injury following hip fracture surgery increases susceptibility to infection in aged rats. Mediators Inflamm 2013; 2013: 536435.

12. Neumaier M, Vester H, Martetschläger F, Freude T. Optimaler Zeitpunkt zur prothetischen Versorgung von Schenkelhalsfrakturen 2011; 82: 921-6.

13. Harwood PJ, Giannoudis PV, van Griensven M, Krettek C, Pape HC. Alterations in the systemic inflammatory response after early total care and damage control procedures for femoral shaft fracture in severely injured patients. J Trauma 2005; 58: 446-52.

14. Nakamura H, Yoshino S, Shiga H, Tanaka H, Katsumata S. A case of spontaneous femoral neck fracture associated with multicentric reticulohistiocytosis: oversecretion of interleukin-1beta, interleukin-6, and tumor necrosis factor alpha by affected synovial cells. Arthritis Rheum 1997; 40: 2266-70.

15. Tiansheng S, Xiaobin C, Zhi L, et al. Is damage control orthopedics essential for the management of bilateral femoral fractures associated or complicated with shock? An animal study. J Trauma 2009; 67: 1402-11.

16. Buzdon MM, Napolitano LM, Shi HJ, et al. Femur fracture induces site-specific changes in T-cell immunity. J Surg Res 1999; 82: 201-8.

17. Pape HC, Grimme K, Van Griensven M, et al. Impact of intramedullary instrumentation versus damage control for femoral fractures on immunoinflammatory parameters: prospective randomized analysis by the EPOFF Study Group. J Trauma 2003; 55: 7-13.

18. Bączyk G, Samborski W, Jaracz K. Evaluation of the quality of life of postmenopausal osteoporotic and osteopenic women with or without fractures. Arch Med Sci 2016; 12: 819-27.
19. Dytfeld J, Marcinkowska M, Drwęska-Matelska N, Michalak M, Horst-Sikorska W. Association analysis of the COL1A1 polymorphism with bone mineral density and prevalent fractures in Polish postmenopausal women with osteoporosis. Arch Med Sci 2016; 12: 288-94.

20. Sadr SSH, Javanbakht J, Norouzi Javidan A, Ghaffarpour M, Safoura Khamse S. Descriptive epidemiology: prevalence, incidence, sociodemographic factors, socioeconomic domains, and quality of life of epilepsy: an update and systematic review. Arch Med Sci 2018; 14 : 717-24. 